Article

\title{
Livestock Performance for Sheep and Cattle Grazing Lowland Permanent Pasture: Benchmarking Potential of Forage-Based Systems
}

\author{
Robert J. Orr ${ }^{1}$, Bruce A. Griffith ${ }^{1}$, M. Jordana Rivero ${ }^{1, *}$ and Michael R. F. Lee ${ }^{1,2}$ \\ 1 Rothamsted Research, Sustainable Agriculture Sciences, North Wyke, Okehampton, Devon EX20 2SB, UK; \\ robert.orr@rothamsted.ac.uk (R.J.O.); bruce.griffith@rothamsted.ac.uk (B.A.G.); \\ michael.lee@rothamsted.ac.uk (M.R.F.L.) \\ 2 University of Bristol, Bristol Veterinary School, Langford, Somerset BS40 5DU, UK \\ * Correspondence: jordana.rivero-viera@rothamsted.ac.uk; Tel.: +44-1837-512302
}

Received: 29 January 2019; Accepted: 18 February 2019; Published: 21 February 2019

\begin{abstract}
Here we describe the livestock performance and baseline productivity over a two-year period, following the establishment of the infrastructure on the North Wyke Farm Platform across its three farmlets (small farms). Lowland permanent pastures were continuously stocked with yearling beef cattle and ewes and their twin lambs for two years in three farmlets. The cattle came into the farmlets as suckler-reared weaned calves at $195 \pm 32.6$ days old weighing $309 \pm 45.0 \mathrm{~kg}$, were housed indoors for 170 days then turned out to graze weighing $391 \pm 54.2 \mathrm{~kg}$ for 177 days. Therefore, it is suggested for predominantly grass-based systems with minimal supplementary feeding that target live weight gains should be $0.5 \mathrm{~kg} /$ day in the first winter, $0.9 \mathrm{~kg} /$ day for summer grazing and $0.8 \mathrm{~kg} / \mathrm{day}$ for cattle housed and finished on silage in a second winter. The sheep performance suggested that lambs weaned at 100 days and weighing $35 \mathrm{~kg}$ should finish at 200 days weighing 44 to $45 \mathrm{~kg}$ live weight with a killing out percentage of $44 \%$. Good levels of livestock production are possible with grass and forage-based systems using little or no additional supplementary concentrate feeds.
\end{abstract}

Keywords: sheep; cattle; grazing; permanent pasture; fertiliser; lowland

\section{Introduction}

Livestock production contributes to greenhouse gas emissions [1]. Amongst a wide range of possible mitigation strategies to either reduce total emissions or reduce emissions intensity is achieving higher productivity, for example, through breeding or through intensive housing and concentrate feeding. Reducing the maintenance cost burden inherent in slow growing animals using intensive systems may be achieved at the cost of certain aspects of animal welfare (ability to express natural behaviour) [2] and will involve feeding human-edible feeds as opposed to grass and forages [3]. However, there is likely to be a benefit in grass and forage pasture-based systems if high quality diets are provided so that the animals' performance can be optimised. The question then is what are reasonable targets when concentrate supplementation is minimal for the weaned calves in each of the production phases after weaning: their first winter; the yearling cattle which graze in the following spring-summer (some of which may achieve finished condition and are sold) and the cattle which require to be housed again for a second winter?

Smil [4] discussed how environmentally sensitive methods of meat production are possible, including systems based on truly sustainable grazing, feeding of forages rotated with food crops and maximum use of crop and processing residues - when combined with moderation of meat consumption. However, UK survey figures for the quantities of concentrates fed to suckler calves after weaning in the finishing phase [5] averaged $1107 \mathrm{~kg} / \mathrm{animal}$. Rearing livestock on non-human edible forages and 
crop residues can provide a moderate supply of meat and other livestock products as an excellent provider of essential nutrients (e.g., vitamin B12, Haeme-Fe, omega-3 fatty acids and other vitamins, minerals and beneficial fatty acids) for a sustainable and balanced diet [6].

Contrasting views on the environmental burdens (e.g., gaseous emissions) of red meat production (e.g., when based on confinement feeding of cattle fed crops grown using groundwater supplies) are the focus of current debate, reflected in increased interest in sustainability of red meat production, supply chain and retail industries and a consideration of these issues is now essential and timely to establish what models of ruminant farming will make the greatest contribution to the resilience of our food system [7]. The potential of forage-based diets should be demonstrated for a wide range of ruminant milk and meat production systems. The challenge for the future development of ruminant systems is to ensure that human-edible feeds or preferably by-products if available locally, are used solely to strategically complement pastures to optimise performance where needed with performance driven by high quality forage grown on farm [3].

The North Wyke Farm Platform (NWFP) provides a means to research, understand and deliver sustainable grazing livestock systems through developing a detailed understanding of sustainability metrics and trade-offs (e.g., productivity, nutritional-quality, biodiversity and emissions). The aim is to deliver optimised production of high value animal products from land not suitable for crop production at the same time as harnessing and protecting other ecosystem services and minimising environmental pollution [8]. The NWFP experiment along with others like it (i.e., those of the Global Farm Platform network that encompass different climatic and eco-regions, see www.globalfarmplatform.org), can address the true position and role of livestock products in sustainable agricultural production and global food security. Sustainable livestock production can produce multiple social, economic and environmental benefits by not only improving productivity but also reducing the ecological footprint and generate diversity of ecosystem services such as improved water, air and soil quality and reduced erosion, sedimentation and greenhouse gas emissions [9].

With the aim of establishing realistic target performance indicators for lowland beef and sheep systems, here we describe the livestock performance and baseline farmlet productivity over a two-year period following the establishment of the research farm infrastructure. We explore and compare the levels of production that can be achieved from lowland permanent pastures when no additional supplementation is fed to grazing animals and only a minimal amount of rolled barley (Hordeum vulgare L.) or concentrates are fed as supplements to grass silage indoors in winter (up to a total of $60 \mathrm{~kg} /$ head over winter housing). This enabled realistic target growth rates to be established for each production phase following weaning for permanent pasture forage-based systems against which subsequent alternative pasture improvements could then be bench-marked and optimised.

\section{Materials and Methods}

The North Wyke Farm Platform was constructed in 2010 [8] in South West England (50 46 $16^{\prime \prime} \mathrm{N}$, $3^{\circ} 54^{\prime} 05^{\prime \prime} \mathrm{W}$ ) on a lowland site at a height of between $126 \mathrm{~m}$ and $180 \mathrm{~m}$ above sea level. The platform (Figure 1) comprises three farmlets (small farms, A, B and C) which were designed to test the productivity and environmental sustainability of contrasting temperate grassland beef and sheep systems at the farm scale. Each of the three farmlets was further divided into five catchments (15 in total) with each catchment being hydrologically isolated through a combination of topography and a network of French drains which were constructed at the edges. These drains channelled the water to monitoring sites, as described in detail by Orr et al. [8]. All areas and distances presented here were geo-referenced and calculated in ArcGIS 10.0 (www.esri.com). 


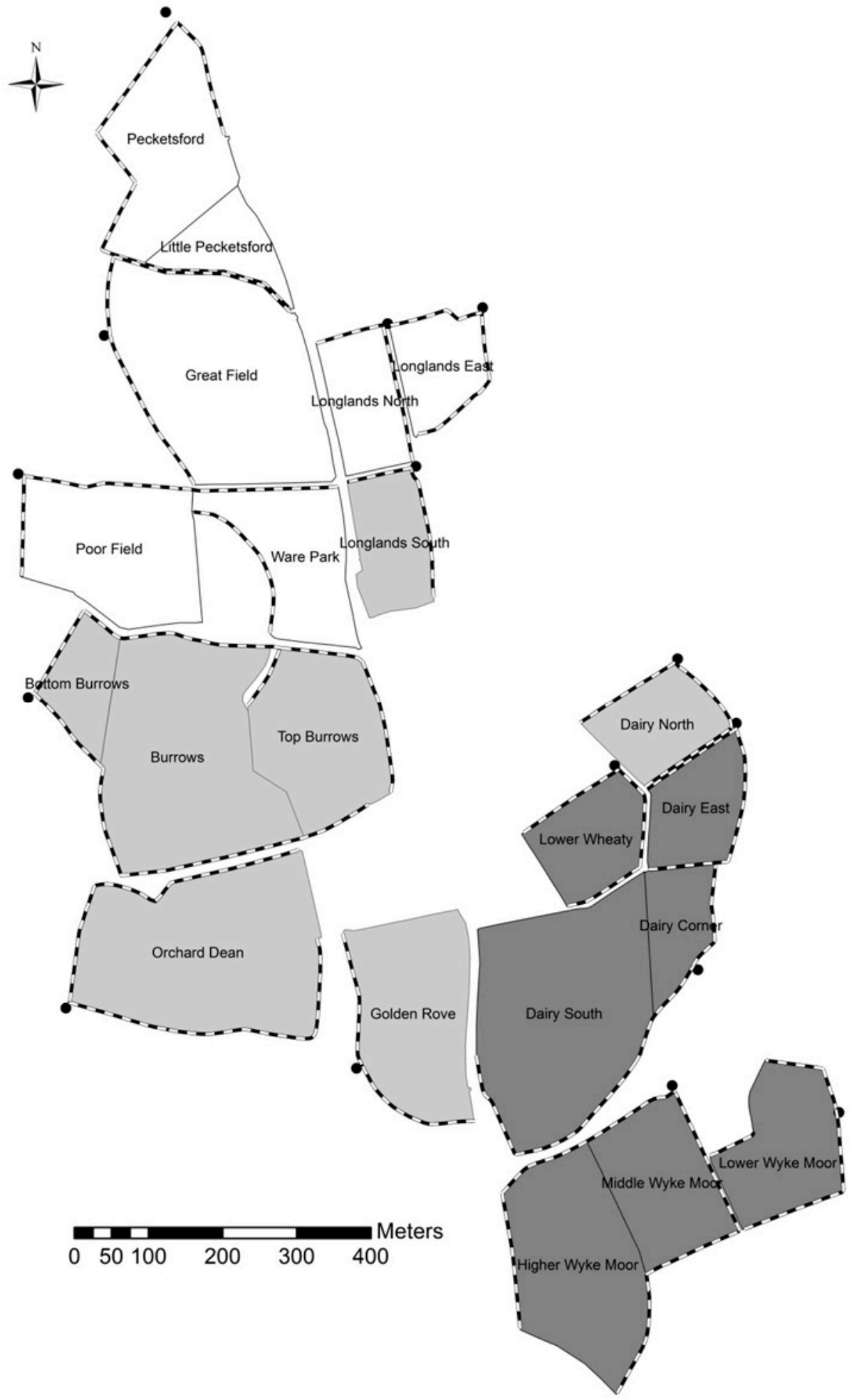

Figure 1. The NWFP farmlets: A ( $\square)$, B ( $\square$ ) and C ( $\square)$ ); French drains ( $\square$ ) and water monitoring sites $(\bullet)$.

Weather data were recorded every $15 \mathrm{~min}$ with an automatic met station installed on-site. Total annual rainfall for 2011 was $835 \mathrm{~mm}$ and for 2012 was $1046 \mathrm{~mm}$. Solar radiation for 2011 and 2012 is shown in Figure 2. 


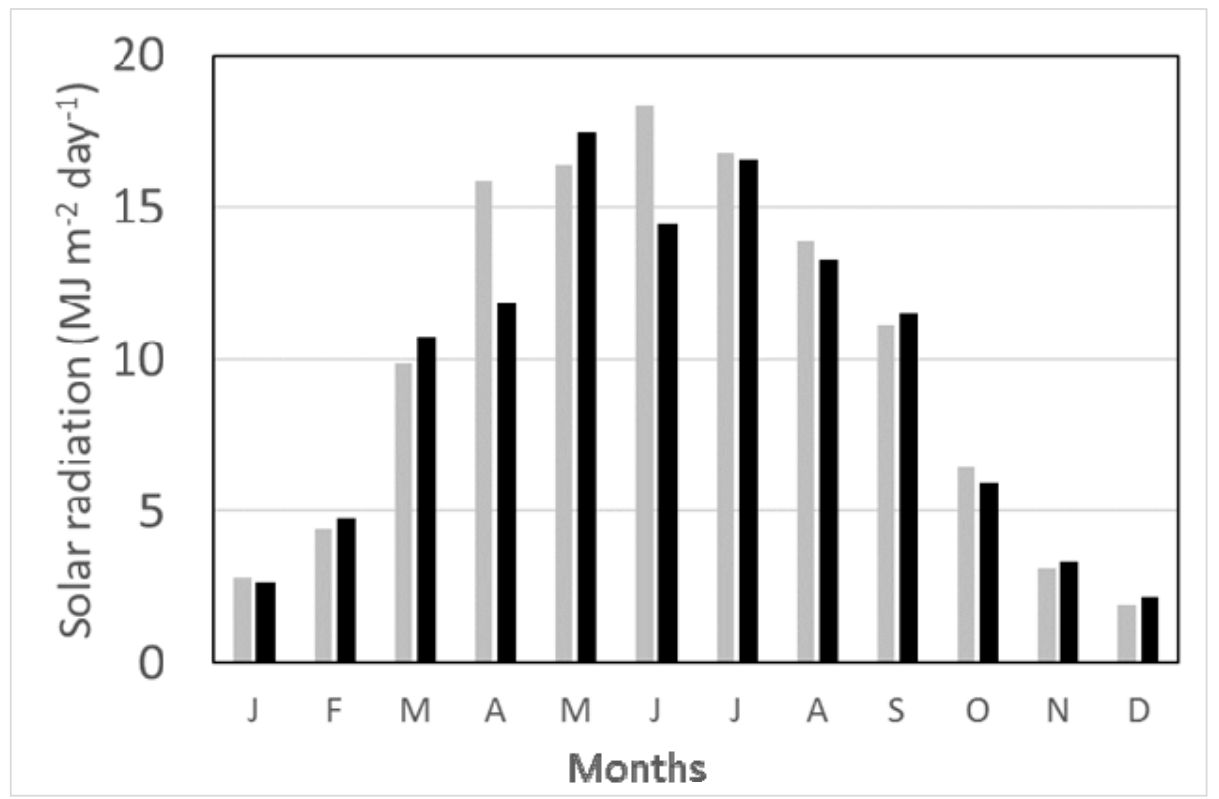

Figure 2. Solar radiation (MJ m ${ }^{-2}$ day $^{-1}$ ) measured in 2011 ( $\square$ ) and 2012 (

\subsection{Farmlet Management}

In two years from 1 April 2011, beef and sheep production systems were run using the same management guidelines on the three farmlets to measure baseline productivity on the existing permanent pasture. After 1 April 2013, two of the farmlets entered a phase where they began to move progressively towards becoming new treatments with either use of legumes in white clover (Trifolium repens L.) targeting 30\% ground cover or by establishing a programme of planned regular reseeding maximising the potential of new grass germplasm through targeted breeding programmes. Here we describe the performance measured during the initial two-year baseline period under permanent pasture.

\subsection{Livestock}

A spring-calving suckler herd at North Wyke ran as a separate enterprise from the NWFP and provided the predominantly Continental (Charolais) $\times$ Hereford-Friesian calves used which grazed with their mothers. At weaning in autumn 2010 and 2011, the calves were housed for their first winter and fed grass silage. In addition, a small amount of concentrates $(1.5 \mathrm{~kg} / \mathrm{head}$ for 26 days, then $0.75 \mathrm{~kg} /$ head for 10 days), containing $3 \%$ fat, $16 \%$ crude protein and $5.7 \%$ fibre, was also fed after weaning to facilitate the change in diet. In each baseline year, there were 25 and 27 cattle per farmlet and in the 2012 grazing season there were five additional Continental $\times$ Hereford-Friesian cattle per farmlet (with a mean date of birth of 1 August 2011) which were purchased and grazed on the NWFP. In the second winter when any remaining cattle (born in 2010) which had not been sold from pasture were housed, a small quantity of rolled barley was fed (1.5 kg/head for 13 days; $3.0 \mathrm{~kg} / \mathrm{head}$ for 13 days) in addition to silage. Barley ( $H$. vulgare $\mathrm{L}$.) was selected given its high nutritional value for cattle at a lower price compared with other supplements and its neglectable effect on meat quality, at the level of feeding [10]. No additional supplementary feed was offered to the cattle born in 2011 when they were housed for their second winter. A March-lambing flock of Suffolk $\times$ Mule (Bluefaced Leicester $\times$ Swaledale) ewes, crossed with Texel or Charollais rams (balanced between the three farmlets), provided the 50 ewes and their twin lambs which also grazed each of the farmlets. The lambs were weaned in July each year then moved to other fields on their respective farmlet which had been cut for silage in May. An additional 50 ewes were drafted into each farmlet after weaning and so 100 ewes grazed each 
farmlet until late December, when they were housed. The cattle and lambs were sold when they were judged to have reached target fat and conformation scores [11,12].

\subsection{Pasture Management and Measurements}

Herbicide was sprayed in some fields to control broad-leaved dock (Rumex obtusifolius L.) and curly dock (Rumex crispus L.) in both years. Higher Wyke Moor and Golden Rove (Figure 1) were sprayed with Mecoprop-PK (54.8\%) and Dicamba-K (7.3\%) on 1 July 2011. Ware Park, Top Burrows and Middle Wyke Moor were sprayed with triclopyr-2-butoxyethyl ester (14.3\%) and fluroxypyr 1-methylheptyl ester (14.8\%) on 4 September 2012.

At the end of the baseline period, the platform was surveyed in July and August 2013 for plant species abundance using the Domin scale [13] on a $50 \mathrm{~m}$ sampling grid with 197 points in total to assess botanical composition. Regarding pasture productivity, calculations were made using the measured silage yield from each farmlet plus estimates of the grazing offtake by the cattle and sheep using intake as a $\%$ of liveweight depending on the physiological stage in the production cycle. The ewes were not weighed in the experiment reported here so a standard weight change [14] of a medium sized lowland ewe (75 kg after lambing) was applied to the number of ewes present each day on the farmlets. The intake ( $\mathrm{g} / \mathrm{kg}$ live weight) was calculated from measurements made on similar lowland ewes by Orr et al. [15] and Parsons et al. [16] and the grazing offtake by the ewes in lactation and after weaning was determined. The herbage intake by lambs before and after weaning was estimated using data from Penning and Gibb [17]. The lambs were not weighed at birth or before weaning and so a mean twin birth weight of $4.9 \mathrm{~kg} / \mathrm{lamb}$ was used based on subsequent data collected at lambing on the NWFP in 2015 (https://nwfp.rothamsted.ac.uk/). Weights were interpolated from birth to weaning and then the lambs were weighed from weaning until sale. It was assumed that lambs began to consume herbage in their fifth week after birth [17]. The grazing intake by the cattle was estimated from their live weight.

\subsection{Grazing Management}

The cattle and sheep were continuously stocked [18] and management plans identified which fields were to be grazed by cattle, grazed by sheep or set aside for silage if not required for grazing to provide winter feed when the livestock were housed. Silage yields were assessed using a Haldrup (www.haldrup.de) plot harvester to sample strips (approximately $10 \mathrm{~m}$ long; measured accurately) which were subsampled for dry matter (DM) percentage before whole fields were cut and the herbage was removed. The herbage yield in each field was calculated from the yield determined using the Haldrup harvester multiplied by the estimated cut area which was calculated using ArcGIS from surveys of uncut field margins. In each year, the silage made in May from each farmlet was combined in the same clamp and the silage made in August was also combined for the farmlets and put into a different clamp.

\subsection{Inorganic and Organic Fertilisers Inputs}

Up to five applications of $40 \mathrm{~kg} \mathrm{~N} /$ ha were planned to be made to the grazed swards at monthly intervals beginning in March each year, depending on ground conditions. In areas, due to be conserved, compound fertiliser containing nitrogen $(\mathrm{N})\left(\mathrm{NH}_{4} \mathrm{NO}_{3} ; 1: 1\right)$, phosphorus $\left(\mathrm{P} ; \mathrm{P}_{2} \mathrm{O}_{5}\right)$ and potassium $(\mathrm{K}$; $\mathrm{K}_{2} \mathrm{O}$ ) was applied in March followed by additional straight $\mathrm{N}$ applications which were made in April. In 2012 only, the compound fertiliser also supplied sulphur (S; $\mathrm{SO}_{3}$, see below). Fields set aside to be cut were rolled in March or April each year. As the cattle and sheep were housed and bedded in winter on purchased barley straw, the farm yard manure (FYM) produced during the housing period was applied at a target rate of $14.7 \mathrm{t} / \mathrm{ha}$ to fields due to be grazed after cuts had been taken for silage. FYM was applied to fields following cutting in May each year, except where it was planned to take another cut in the same field later in the season (e.g., Pecketsford, Burrows and Middle Wyke Moor in 2011). These fields then received FYM following cutting in August 2011. In total, between June 2011 and August 2012, farmlets A, B and C received 323.4, 367.5 and 318.5 t of FYM, respectively. 
Inorganic fertilisers were not spread within $2 \mathrm{~m}$ of water courses because the NWFP is in a UK Nitrate Vulnerable Zone (www.gov.uk/nitrate-vulnerable-zones), hence the areas where fertiliser was applied were smaller than the fenced areas (Table 1). For farmlets A, B and C, respectively, the mean rate of application was 204, 207 and 205 in 2011 and 111, 110 and $108 \mathrm{~kg} \mathrm{N/fenced} \mathrm{ha} \mathrm{in} \mathrm{2012.} \mathrm{Fewer} \mathrm{total}$ applications were made in 2012, partly because of high levels of pasture growth in the sheep swards in March and April when applications were omitted. Also, this was followed by exceptional and extreme rainfall events in June and July 2012 which resulted in the cattle being housed for 19 days and, once again, applications were omitted whilst a vegetative pasture structure was re-established.

Table 1. Inorganic $\mathrm{N}, \mathrm{P}_{2} \mathrm{O}_{5}$ and $\mathrm{K}_{2} \mathrm{O}$ fertiliser applications in 2011 and 2012 and $\mathrm{SO}_{3}$ fertiliser applications in 2012.

\begin{tabular}{|c|c|c|c|c|c|c|c|c|c|}
\hline \multirow[t]{2}{*}{ Farmlet } & \multirow{2}{*}{$\begin{array}{c}\begin{array}{c}\text { Fenced } \\
\text { Area }\end{array} \\
\text { (ha) }\end{array}$} & \multirow{2}{*}{$\begin{array}{c}\begin{array}{c}\text { Fertilised } \\
\text { Area }\end{array} \\
\text { (ha) }\end{array}$} & \multicolumn{2}{|c|}{$\begin{array}{l}\text { Total N } 1 \\
(\mathrm{~kg})\end{array}$} & \multirow{2}{*}{$\begin{array}{c}\begin{array}{c}\text { Total } \mathrm{SO}_{3} \\
(\mathbf{k g})\end{array} \\
2012 \\
\end{array}$} & \multicolumn{2}{|c|}{$\begin{array}{l}\text { Total } \mathrm{P}_{2} \mathrm{O}_{5} \\
\text { (kg) }\end{array}$} & \multicolumn{2}{|c|}{$\begin{array}{c}\text { Total } \mathrm{K}_{2} \mathrm{O} \\
(\mathrm{kg})\end{array}$} \\
\hline & & & 2011 & 2012 & & 2011 & 2012 & 2011 & 2012 \\
\hline A & 21.34 & 20.93 & 4362 & 2364 & 314 & 444 & 359 & 1709 & 1324 \\
\hline B & 25.05 & 24.58 & 5161 & 2760 & 413 & 556 & 472 & 1824 & 1309 \\
\hline C & 20.95 & 20.63 & 4303 & 2263 & 286 & 548 & 327 & 1549 & 1003 \\
\hline
\end{tabular}

${ }^{1} \mathrm{NH}_{4} \cdot \mathrm{NO}_{3} ; 1: 1$.

The compound fertilisers used on the fields due to be cut contained $\mathrm{S}$ as an additional constituent only in 2012 (Table 1) and the overall weighted mean application rate across the farmlets was $15 \mathrm{~kg}$ $\mathrm{SO}_{3} /$ fenced ha. In 2011 and 2012, respectively, the overall mean application rates of inorganic $\mathrm{P}$ and $\mathrm{K}$ (Table 1) were 23 and $17 \mathrm{~kg} \mathrm{P}_{2} \mathrm{O}_{5} /$ fenced ha and 76 and $54 \mathrm{~kg} \mathrm{~K}_{2} \mathrm{O} /$ fenced ha across the farmlets. Target soil indices were $\mathrm{P}$ index $2(16-25 \mathrm{mg} / \mathrm{kg})$ and $\mathrm{K}$ index $2-(121-180 \mathrm{mg} / \mathrm{kg})$ and muriate of potash was applied to those individual fields which were below target.

\subsection{Statisitcal Approach}

Results are presented with summary statistics, average \pm standard deviation (SD), since the main objective is to describe and establish a realistic benchmark for lowland permanent pasture-based sheep and beef systems. To account for the potential variability between years, analysis of variance was performed to compare mean results per farmlet between 2011 and 2012, considering the farmlet as a block (replicate). The units of measurement were either the individual animals (lambs and growing cattle) or the individual fields, depending on the variables analysed (animal performance or pasture productivity). The experimental unit was the farmlet (replicate). The statistical model used was the following:

$$
Y_{i j}=\mu+A_{i}+B_{j}+\text { random error }
$$

where $Y_{i j}$ is any observation for which $i$ is the year and $j$ is the block (farmlet), $\mu$ is the overall mean, $A_{i}$ is the effect for being in year $i$ and $B_{j}$ is the effect for being farmlet $j$. Significance level was established at $p<0.05$ and tendency at $p<0.10$. The Genstat ${ }^{\circledR}$ (CVSN International Ltd., Hemel Hempstead, UK) statistical system was used for the analysis.

\section{Results}

\subsection{Pasture}

On average these permanent pastures contained covers of $64 \%$ Lolium perenne L., $38 \%$ Agrostis stolonifera L., $2 \%$ Holcus lanatus L. and $1 \%$ Alopecurus geniculatus L. as the main constituents (Table 2). 
Table 2. Average percentage cover of plant species in July/August 2013, recorded as Domin using the classification of Rodwell [13].

\begin{tabular}{cccc}
\hline & \multicolumn{3}{c}{ Farmlet } \\
\hline Common Name (Botanical Name) & A & $\begin{array}{c}\text { B } \\
\text { Cover (\% } \pm \text { SD) }\end{array}$ & C \\
\hline Perennial ryegrass (Lolium perenne L.) & $66.3 \pm 29.35$ & $60.4 \pm 30.00$ & $69.0 \pm 27.55$ \\
Creeping bent (Agrostis stolonifera L.) & $34.6 \pm 30.57$ & $43.8 \pm 30.50$ & $29.7 \pm 26.58$ \\
Yorkshire fog (Holcus lanatus L.) & $0.1 \pm 0.50$ & $1.4 \pm 4.51$ & $6.6 \pm 17.00$ \\
Marsh foxtail (Alopecurus geniculatus L.) & $3.0 \pm 7.6$ & $0.4 \pm 2.0$ & $0.1 \pm 1.00$ \\
Rough stalked meadow-grass (Poa trivialis L.) & - & - & $0.1 \pm 0.62$ \\
Timothy (Phleum pratense L.) & - & - & $0.1 \pm 0.50$ \\
Creeping buttercup (Ranunculus repens L.) & $0.5 \pm 1.50$ & $0.1 \pm 0.46$ & $0.2 \pm 0.71$ \\
Dandelion (Taraxacum officinale L.) & $0.1 \pm 0.37$ & - & $0.3 \pm 1.12$ \\
Soft rush (Juncus effusus L.) & - & $0.4 \pm 4.31$ & - \\
Broad-leaved dock (Rumex obtusifolius L.) & $0.2 \pm 0.98$ & $0.1 \pm 0.72$ & - \\
Curly dock (Rumex crispus L.) & $0.3 \pm 2.47$ & - & $0.1 \pm 0.36$ \\
Mouse-ear chickweed (Cerastium fontanum L.) & - & - & $0.1 \pm 0.38$ \\
White clover (Trifolium repens L.) & - & & \\
\hline
\end{tabular}

Overall the silage yield plus grazing offtake was greater $(p=0.028)$ in 2011 than in $2012(9.9 \pm 0.54 \mathrm{t}$ v. $7.1 \pm 0.35 \mathrm{t} \mathrm{DM} / \mathrm{ha}$ ) (Figure 3). This was mainly due to the greater $(p=0.012)$ silage production in 2011 compared with 2012 ( $5.5 \pm 0.32$ v. $2.2 \pm 0.41$ t DM/ha). On the other hand, sheep offtake (ewes plus lambs) was greater in 2012 compared with 2011 ( $2.1 \pm 0.18$ v. $2.7 \pm 0.11 \mathrm{t} \mathrm{DM} / \mathrm{ha})$. However, cattle offtake did not differ between years (averaged $2.2 \pm 0.17 \mathrm{t} \mathrm{DM} / \mathrm{ha}$ ). Overall, the grazing offtake tended ( $p=0.058)$ to be higher in 2012 than 2011 (4.9 $\pm 0.26 \mathrm{v} .4 .4 \pm 0.32 \mathrm{t} \mathrm{DM} / \mathrm{ha})$. The decision for the increase from 25 to 27 cattle per farmlet from 2011 to 2012, plus 5 younger autumn-born cattle per farmlet in 2012 was influenced by the fact that the grazing offtake comprised less than half (44\%) of the total output in 2011, whilst in 2012 increased to $69 \%$.

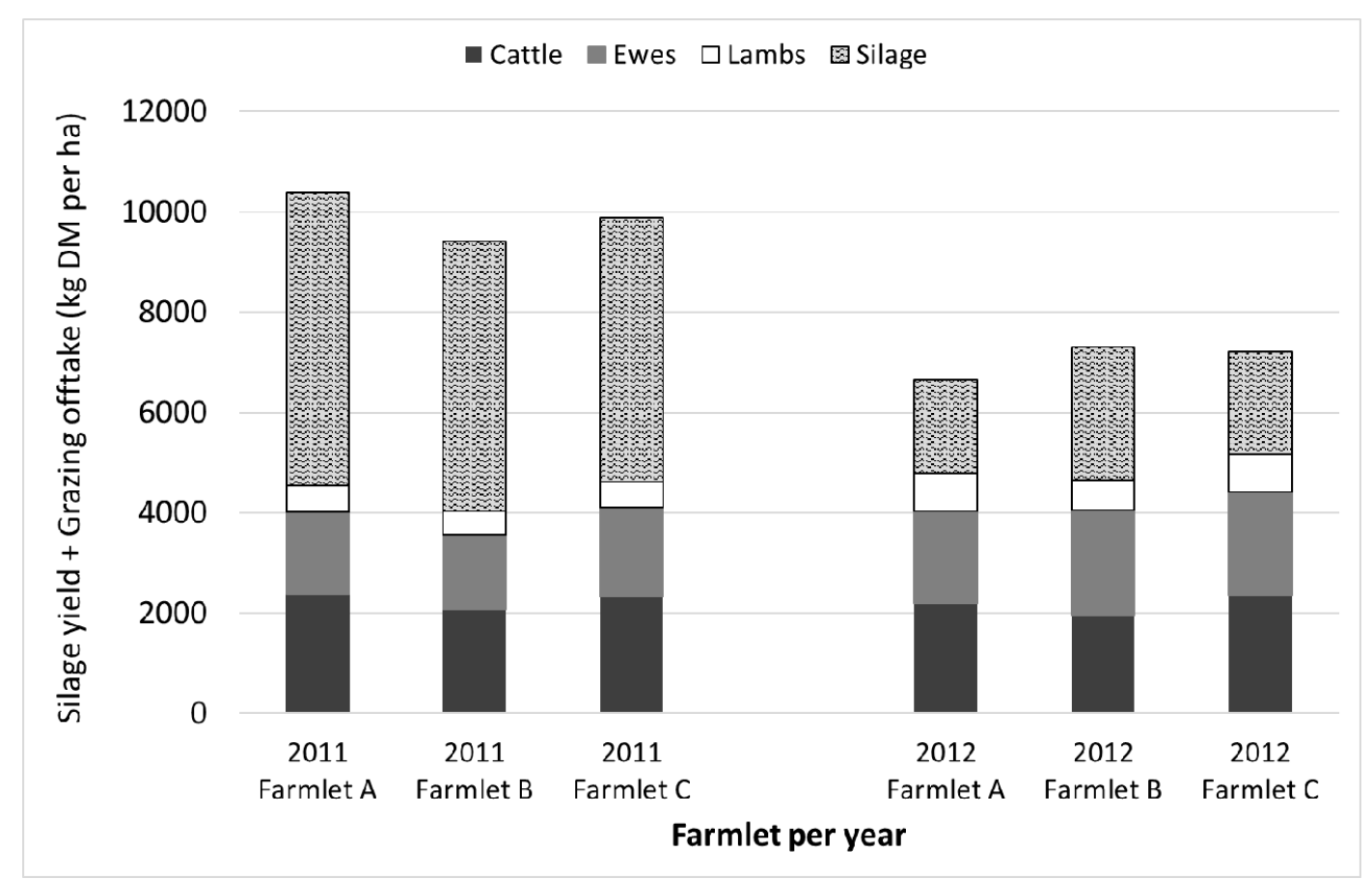

Figure 3. Silage yield plus grazing offtake $\left(\mathrm{kg} \mathrm{DM} \mathrm{ha}^{-1}\right)$ by cattle, ewes and lambs for farmlets $\mathrm{A}, \mathrm{B}$ and $C$ in 2011 and 2012. 


\subsection{Yield of Herbage Cut and Analyses of Silage Made}

Yields of herbage cuts for farmlets A, B and C are presented in Table 3. The overall weighted mean yield within each farmlet in May 2011 was 7154, 6021 and $6168 \mathrm{~kg}$ DM/ha; in August 2011 was 4871, 4864 and $5594 \mathrm{~kg}$ DM/ha; in May 2012 was 4031, 3843 and 3279 kg DM/ha; in August 2012 was 0, 3806 and $5197 \mathrm{~kg} \mathrm{DM} / \mathrm{ha}$, respectively.

Table 3. Yield of herbage cut for silage on May and August 2011 and 2012.

\begin{tabular}{ccccccccc}
\hline & \multicolumn{3}{c}{2011} & \multicolumn{2}{c}{2012} \\
\hline Farmlet & $\begin{array}{c}\text { Area Cut } \\
\text { (ha) }\end{array}$ & $\begin{array}{c}\text { Herbage } \\
\text { Yield (t } \\
\text { DM) }\end{array}$ & $\begin{array}{c}\text { Area Cut } \\
\text { (ha) }\end{array}$ & $\begin{array}{c}\text { Herbage } \\
\text { Yield (t } \\
\text { DM) }\end{array}$ & $\begin{array}{c}\text { Area Cut } \\
\text { (ha) }\end{array}$ & $\begin{array}{c}\text { Herbage } \\
\text { Yield (t } \\
\text { DM) }\end{array}$ & $\begin{array}{c}\text { Area Cut } \\
\text { (ha) }\end{array}$ & $\begin{array}{c}\text { Herbage } \\
\text { Yield (t } \\
\text { DM) }\end{array}$ \\
\hline A & 12.59 & 90.1 & 7.26 & 35.3 & 9.87 & 39.8 & & \\
B & 17.26 & 103.9 & 6.28 & 30.5 & 13.44 & 51.6 & 3.77 & 14.4 \\
C & 11.5 & 70.9 & 6.86 & 38.4 & 8.87 & 29.1 & 2.63 & 13.6 \\
\hline
\end{tabular}

The silage analyses (Table 4) indicated that, apart from the silage made in August 2012, the digestibility (DOMD) was above $700 \mathrm{~g}$ digestible organic matter (DOM) per $\mathrm{kg}$ DM and estimated metabolizable energy (ME) was above 11.0 MJ/kg DM. The low digestibility silage made in August 2012 had higher crude protein concentration than was measured in the other silages. The silage made in 2011 had higher DM \% than those made in the following year, but all silages were well preserved with low $\mathrm{pH}(<4.1)$. Ammonia $\mathrm{N}$ was lower in the first cut silages made in May (mean $60 \mathrm{~g} / \mathrm{kg}$ total $\mathrm{N}$ ) than those made in August (mean $110 \mathrm{~g} / \mathrm{kg}$ total N). Analysis of the concentrations of fermentation acids made in May in both years and in August 2012 indicated that a predominantly lactic acid fermentation had been achieved.

Table 4. Chemical analyses, reported on a dry matter (DM) basis, for silages made following harvest in 2011 and 2012.

\begin{tabular}{|c|c|c|c|c|c|}
\hline & \multicolumn{4}{|c|}{ Harvest Date } & \multirow[b]{2}{*}{$\begin{array}{c}\text { Standard } \\
\text { Range }^{1}\end{array}$} \\
\hline & $\begin{array}{l}\text { May } \\
2011\end{array}$ & $\begin{array}{l}\text { May } \\
2012\end{array}$ & August 2011 & August 2012 & \\
\hline $\mathrm{DOMD}(\mathrm{g} \text { DOM } / \mathrm{kg})^{2}$ & 710 & 710 & 700 & 670 & 620 to 680 \\
\hline $\mathrm{ME}(\mathrm{MJ} / \mathrm{kg})^{3}$ & 11.3 & 11.4 & 11.2 & 10.7 & 10.0 to 11.0 \\
\hline Crude protein (g/kg) & 111 & 121 & 120 & 150 & 69 to 209 \\
\hline $\operatorname{NDF}(\mathrm{g} / \mathrm{kg})^{4}$ & 518 & 484 & 599 & 487 & 193 to 681 \\
\hline Ash (g/kg) & 68 & 79 & 65 & 92 & 53 to 125 \\
\hline $\mathrm{DM}(\mathrm{g} / \mathrm{kg})$ & 326 & 236 & 293 & 242 & 155 to 431 \\
\hline $\mathrm{pH}$ & 4.0 & 3.7 & 4.1 & 4.1 & 3.7 to 5.1 \\
\hline Ammonia $\mathrm{N}(\mathrm{g} / \mathrm{kg}$ total $\mathrm{N})$ & 54 & 66 & 102 & 118 & 110 to 210 \\
\hline Acetic acid $(\mathrm{g} / \mathrm{kg})$ & 10.5 & 26.1 & t & 23.1 & 28 to 57 \\
\hline Butyric acid (g/kg) & 0.3 & 2.5 & + & 6.6 & 20 to 39 \\
\hline Lactic acid (g/kg) & 76.1 & 101.9 & + & 74.2 & 50 to 100 \\
\hline Total acids (g/kg) & 87.2 & 132.2 & + & 111.7 & 85 to 170 \\
\hline
\end{tabular}

\subsection{Cattle Performance}

The spring-born calves were born on average $( \pm$ SD) on 25 March $2010( \pm 64 \mathrm{~d})$ and 25 February 2011 ( $\pm 93 \mathrm{~d}$ ) (Table 5) for the two baseline years, respectively. They were (mean \pm SD) one month older $(180 \pm 33.5$ v. $211 \pm 22.6$ days old $)$ and weighed $18 \mathrm{~kg}$ more $(300 \pm 45.5 \mathrm{v} .318 \pm 42.3 \mathrm{~kg})$ when they were weaned and housed in October 2010 and 2011, respectively. The cattle were turned out 
to graze on 13 April 2011 (25 per farmlet) and 13 April 2012 (27 per farmlet) when they weighed $386 \pm 59.7$ and $395 \pm 47.9 \mathrm{~kg}$, respectively, with no difference between years $(p=0.077)$. At the end of each grazing season, after some had been sold whilst they were at pasture (45 in 2011 and 21 in 2012), those remaining on each farmlet were housed on 3 November 2011 (30 animals in total) and, in the second year (60 animals in total), on 28 September 2012 (Farmlet A) or 3 October 2012 (Farmlets $B$ and C). For the two baseline years, when the cattle were sold they were $599 \pm 80.6$ and $629 \pm 79.9$ days old, with no difference between years, although a tendency was observed $(p=0.061)$. They weighed $594 \pm 25.0$ and $590 \pm 57.3 \mathrm{~kg}$ before sale, with no difference between years $(p=0.517)$ and had net carcase weights of $305 \pm 29.7$ and $300 \pm 30.9 \mathrm{~kg}$, with no difference between years $(p=0.410)$. The killing out percentages were $51.3 \pm 1.63 \%$ and $51.0 \pm 1.59 \%$, with no difference between years $(p=0.371)$, for 2011 and 2012, respectively.

Table 5. Live weights (LW) and sales data for cattle born in spring 2010 (25 heads per farmlet) and spring 2011 (27 heads per farmlet) (average \pm SD).

\begin{tabular}{|c|c|c|c|c|c|c|}
\hline & \multicolumn{3}{|c|}{$\begin{array}{l}2011 \text { Grazing Year } \\
\text { Farmlet }\end{array}$} & \multicolumn{3}{|c|}{$\begin{array}{l}2012 \text { Grazing Year } \\
\text { Farmlet }\end{array}$} \\
\hline & $\mathbf{A}$ & B & $\mathrm{C}$ & $\mathbf{A}$ & B & $\mathrm{C}$ \\
\hline Weaning age (days) & $183 \pm 32.1$ & $175 \pm 37.0$ & $182 \pm 33.0$ & $209 \pm 26.6$ & $214 \pm 22.3$ & $209 \pm 20.8$ \\
\hline Weaning LW (kg) & $299 \pm 56.0$ & $303 \pm 44.1$ & $298 \pm 37.2$ & $313 \pm 45.5$ & $321 \pm 44.9$ & $319 \pm 39.8$ \\
\hline $\mathrm{LW}$ at turnout ${ }^{1}(\mathrm{~kg})$ & $388 \pm 68.0$ & $386 \pm 60.8$ & $385 \pm 52.9$ & $392 \pm 55.5$ & $396 \pm 45.1$ & $398 \pm 44.8$ \\
\hline Age at sale (days) & $601 \pm 47.7$ & $606 \pm 88.9$ & $591 \pm 87.0$ & $635 \pm 88.7$ & $647 \pm 87.2$ & $606 \pm 60.1$ \\
\hline LW at sale $(\mathrm{kg})$ & $601 \pm 68.0$ & $592 \pm 48.8$ & $597 \pm 47.8$ & $588 \pm 61.2$ & $592 \pm 56.9$ & $591 \pm 57.0$ \\
\hline $\begin{array}{l}\text { No. of cattle sold during } \\
\text { the grazing season }\end{array}$ & 14 & 14 & 17 & 16 & 4 & 13 \\
\hline Net carcass weight $(\mathrm{kg})$ & $311 \pm 35.1$ & $300 \pm 21.4$ & $304 \pm 26.1$ & $297 \pm 25.7$ & $299 \pm 34.9$ & $304 \pm 32.9$ \\
\hline Killing out \% & $51.7 \pm 1.67$ & $50.6 \pm 1.41$ & $51.6 \pm 1.68$ & $51.2 \pm 1.34$ & $50.8 \pm 1.99$ & $51.1 \pm 1.43$ \\
\hline
\end{tabular}

${ }^{1}$ Turned out 13 April 2011 and 13 April 2012.

In the second year, the additional five cattle per farmlet were turned out to graze on 27 March 2012 (Table 6). These were born on average on 1 August 2011 ( $\pm 29 \mathrm{~d}$ ), weighed $237 \pm 27.3 \mathrm{~kg}$ at turnout, $372 \pm 36.4 \mathrm{~kg}$ at housing in 2012 and $456 \pm 50.8 \mathrm{~kg}$ at the end of the baseline period when they remained on their respective farmlets and joined the next generation of cattle in the production cycle to graze in 2013. Overall the calves spent 170 days indoors in their first winter; 177 days at pasture and then those cattle which required to be housed again for a second winter in the finishing period spent a further 69 days before being sold. For 2011, cattle growth rate in the first winter $(0.53 \pm 0.012$ v. $0.44 \pm 0.012 \mathrm{~kg} /$ day; $p=0.012)$ and at pasture $(1.02 \pm 0.022 \mathrm{v} .0 .89 \pm 0.022 \mathrm{~kg} /$ day; $p=0.019)$ were greater than in 2012. However, the growth rate of cattle housed for a second winter did not differ between years $(p=0.249)$ and averaged $0.91 \pm 0.160 \mathrm{~kg} /$ day (Table 7). In 2012 the cattle were housed for 19 days between 26 April and 13 May because of high levels of rainfall when the ground became saturated; approximately double $(108 \mathrm{~mm})$ the previous 10-year average April rainfall $(53 \mathrm{~mm})$ was measured in 2012.

Table 6. Live weights for cattle born in summer 2011 during the 2012 grazing season ( 5 heads per farmlet).

\begin{tabular}{cccc}
\hline \multicolumn{4}{c}{ Farmlet } \\
\hline & A & B & C \\
\hline Live weight at turnout $^{1}(\mathrm{~kg})$ & $241 \pm 23.5$ & $239 \pm 39.5$ & $232 \pm 25.0$ \\
Live weight at housing $(\mathrm{kg})$ & $369 \pm 34.6$ & $370 \pm 47.0$ & $378 \pm 37.0$ \\
Live weight 31/3/2013 $(\mathrm{kg})$ & $455 \pm 39.9$ & $455 \pm 65.2$ & $457 \pm 54.5$ \\
\hline \multicolumn{4}{c}{ Turned out 27/3/2012. }
\end{tabular}


Table 7. Daily liveweight gain (DLWG) for cattle born in spring 2010 and 2011 when housed after weaning in their 1st winter; at pasture and then when housed again in their 2nd winter (numbers within parenthesis represent the number of animals present in each stage).

\begin{tabular}{ccccccc}
\hline & \multicolumn{7}{c}{ Farmlet } \\
\hline & No. of Days & $\begin{array}{c}\text { DLWG } \\
\mathbf{( k g / d a y )}\end{array}$ & No. of Days & $\begin{array}{c}\text { DLWG } \\
\mathbf{( k g / d a y )}\end{array}$ & No. of Days & $\begin{array}{c}\text { DLWG } \\
\mathbf{( k g / d a y )}\end{array}$ \\
\hline Born spring 2010 & & & & & & \\
1st winter & $171(25)$ & $0.54 \pm 0.120$ & $170(25)$ & $0.50 \pm 0.159$ & $171(25)$ & $0.54 \pm 0.157$ \\
At pasture & $189(25)$ & $1.05 \pm 0.154$ & $194(25)$ & $0.99 \pm 0.173$ & $183(25)$ & $1.01 \pm 0.062$ \\
2nd winter & $64(11)$ & $0.92 \pm 0.431$ & $55(11)$ & $0.76 \pm 0.384$ & $79(8)$ & $0.74 \pm 0.186$ \\
Born spring 2011 & & & & & & \\
1st winter & $170(27)$ & $0.46 \pm 0.170$ & $170(27)$ & $0.39 \pm 0.111$ & $170(27)$ & $0.46 \pm 0.164$ \\
At pasture & $162(27)$ & $0.93 \pm 0.151$ & $171(27)$ & $0.83 \pm 0.137$ & $164(27)$ & $0.91 \pm 0.152$ \\
2nd winter & $77(19)$ & $0.87 \pm 0.208$ & $69(23)$ & $1.12 \pm 0.335$ & $68(18)$ & $1.06 \pm 0.237$ \\
\hline
\end{tabular}

\subsection{Sheep Performance}

For the two baseline years, respectively, the mean lamb birth dates were 29 March $2011( \pm 6.5 \mathrm{~d})$ and 30 March 2012 ( $\pm 5.7 \mathrm{~d})$. At weaning the lambs were 97 ( $\pm 6.5 \mathrm{~d})$ and 93 ( $\pm 5.7 \mathrm{~d})$ days old (Table 8 ). Weaning weights were greater $(p=0.004)$ in 2011 compared with $2012(35.2 \pm 5.23$ vs. $29.7 \pm 4.81 \mathrm{~kg})$. Of the original total of 300 lambs for each year they were either sold finished (93 and $89 \%$ ) or sold as store lambs (6 and 9\%) with the remainder lost due to mortality (1 and $2 \%)$. The average daily weight gain from weaning to sale was $191 \pm 65.0$ and $136 \pm 53.6 \mathrm{~g} /$ day for lambs weaned in 2011 and 2012, respectively, with no difference between years $(p=0.124)$. For the finished lambs, age at slaughter was greater $(p=0.025)$ in 2012 compared with 2011 (203 \pm 10.6 v. $148 \pm 10.6 \mathrm{~d}$ old) but with similar $(p=0.819)$ final live weights $(44.9 \pm 2.32$ and $44.7 \pm 2.99 \mathrm{~kg})$. Net carcase weights $(19.9 \pm 1.10$ and 18.3 $\pm 1.66 \mathrm{~kg})$ were similar $(p=0.138)$ whilst the killing out percentages were greater $(p=0.028)$ in 2011 compared with $2012(44.2 \pm 3.65 \%$ v. $40.9 \pm 2.47 \%)$.

Table 8. Live weights (LW) and sales data for twin lambs in 2011 and 2012 grazing years (100 lambs per farmlet each year).

\begin{tabular}{|c|c|c|c|c|c|c|}
\hline & \multicolumn{3}{|c|}{$\begin{array}{l}2011 \text { Grazing Year } \\
\text { Farmlet }\end{array}$} & \multicolumn{3}{|c|}{$\begin{array}{c}2012 \text { Grazing Year } \\
\text { Farmlet }\end{array}$} \\
\hline & A & B & $\mathrm{C}$ & A & B & $\mathrm{C}$ \\
\hline Weaning age ${ }^{1}$ (days) & $96 \pm 6.4$ & $97 \pm 6.7$ & $97 \pm 6.4$ & $92 \pm 7.0$ & $93 \pm 4.9$ & $94 \pm 4.8$ \\
\hline Weaning LW (kg) & $34.0 \pm 4.81$ & $35.0 \pm 5.29$ & $36.5 \pm 5.34$ & $27.8 \pm 4.21$ & $29.9 \pm 4.84$ & $31.3 \pm 4.75$ \\
\hline Total no. of lambs sold & 100 & 98 & 99 & 98 & 97 & 97 \\
\hline Age at sale (days) & $153 \pm 26.7$ & $157 \pm 37.9$ & $148 \pm 31.5$ & $216 \pm 25.2$ & $189 \pm 30.0$ & $212 \pm 28.2$ \\
\hline No. of lambs sold finished & 96 & 87 & 96 & 89 & 92 & 85 \\
\hline Finished-age at sale $(\mathrm{d})$ & $150 \pm 23.6$ & $149 \pm 33.4$ & $146 \pm 29.3$ & $214 \pm 24.2$ & $186 \pm 27.1$ & $208 \pm 27.5$ \\
\hline Finished LW at sale (kg) & $45.5 \pm 2.09$ & $44.5 \pm 2.51$ & $44.7 \pm 2.27$ & $43.8 \pm 3.30$ & $45.9 \pm 2.94$ & $44.3 \pm 2.21$ \\
\hline Cold carcass weight (kg) & $20.4 \pm 1.08$ & $19.6 \pm 1.10$ & $19.6 \pm 0.95$ & $17.9 \pm 1.57$ & $19.3 \pm 1.52$ & $17.6 \pm 1.33$ \\
\hline Killing out $\%$ & $44.9 \pm 1.99$ & $44.3 \pm 3.02$ & $43.5 \pm 5.11$ & $41.0 \pm 2.34$ & $42.1 \pm 1.93$ & $39.6 \pm 2.51$ \\
\hline No. of lambs sold as stores & 4 & 11 & 3 & 9 & 5 & 12 \\
\hline Stores-age at sale (d) & $218 \pm 7.0$ & $215 \pm 5.1$ & $220 \pm 7.6$ & $240 \pm 23.6$ & $243 \pm 16.9$ & $238 \pm 17.6$ \\
\hline Stores LW at sale $(\mathrm{kg})$ & $36.6 \pm 3.09$ & $40.6 \pm 2.15$ & $41.7 \pm 0.76$ & $36.3 \pm 4.15$ & $36.2 \pm 7.16$ & $35.6 \pm 4.67$ \\
\hline
\end{tabular}

${ }^{1}$ Weaning dates were 4/7/2011 and 2/7/2012.

\section{Discussion}

\subsection{Farm Yard Manure}

The levels of farmyard manure applied were based on estimates of the quantities produced in 2011 and 2012 by the cattle and sheep. According to the Agriculture and Horticulture Development Board's Nutrient Management Guide [19] the average amount of FYM applied per ha (14.7 ton) would 
have provided approximately: $88 \mathrm{~kg}$ of total $\mathrm{N}$ and 9, 28, 106, 35 and $26 \mathrm{~kg}$ of pasture available $\mathrm{N}, \mathrm{P}, \mathrm{K}, \mathrm{S}$ and magnesium $(\mathrm{Mg})$, respectively. This represents a significant saving in the annual amount of inorganic fertilizer applied to the farmlets since the amount of nutrients returned via FYM represented up to $80 \%$ of the inorganic $\mathrm{N}$ applied per ha, while for $\mathrm{P}$, $\mathrm{K}$ and $\mathrm{S}$ surpass $100 \%$ of inorganic applications per year, even incorporating a relevant amount of $\mathrm{Mg}$ and other micro-nutrients not measured here. These nutrients returned via organic fertilizer also has the potential of enhancing soil quality by improving soil organic carbon content, microbial biomass and soil $\mathrm{CO}_{2}-\mathrm{C}$ flux and is a crucial component of sustainable livestock production systems [20].

\subsection{Pasture Species Composition and Productivity}

Rodwell [13] classifies these permanent pastures, containing A. stolonifera L., as a sub-community of MG6 Lolium perenne L.-Cynosurus cristatus L. grassland. Davies [21] classified first grade pastures as those containing more than $30 \% \mathrm{~L}$. perenne $\mathrm{L}$. and these pastures were found to contain covers of $64 \%$. Therefore, it might be expected that high levels of pasture growth and animal performance could be achieved depending on the season and weather conditions.

Rutter et al. [22] measured intake values of $22.5 \mathrm{~g} \mathrm{DM} / \mathrm{kg}$ live weight for yearling cattle at pasture weighing $308 \mathrm{~kg}$ when growing at $0.97 \mathrm{~kg} /$ day and this value was applied to cattle live weights carried over the season to estimate grazing offtake. This value is similar to other reported intake values of $22.9 \mathrm{~g} \mathrm{DM} / \mathrm{kg}$ live weight for growing cattle of 300 to $400 \mathrm{~kg}$ live weight fed coarse diets with a metabolizability of dietary energy of 0.7 [23].

The greater pasture productivity observed in 2011 compared to 2012 reflected the $25 \%$ higher total annual rainfall measured in 2012 compared with 2011, the lower levels of solar radiation measured-particularly in April 2012 (15.9 and 11.9 MJ m²/day) and June 2012 (18.3 and 14.4 MJ $\mathrm{m}^{-2}$ /day) and the lower levels of inorganic $\mathrm{N}$ fertiliser used in 2012 (205 and $110 \mathrm{~kg} \mathrm{~N} / \mathrm{ha}$ ) because of the adverse weather conditions. The total (grazing plus silage) yield in 2011 was low compared to figures reported by Orr et al. [24] for intermediate heading sown swards of perennial ryegrass when either cut eight times per season (mean $12.1 \mathrm{t} \mathrm{DM} / \mathrm{ha}$ ) or continuously stocked with sheep $(11.7 \mathrm{t}$ $\mathrm{DM} / \mathrm{ha}$ ). This perhaps illustrates the potential of reseeded swards to have higher yield compared with permanent pasture and will be tested in future years at the NWFP.

\subsection{Silage Analyses}

In each year, the analyses of the silage indicated that well preserved silages were made which had predominantly lactic acid fermentation. In a programme using multiple regression analyses to derive equations to predict silage intake from silage and animal factors in mid-pregnancy [25], late pregnancy $[26,27]$ and in early lactation [28] the main significant silage factors were digestibility in vitro, crude protein and dry matter \%, all of which had positive effects. Silage analytical data (http://www.sciantec.uk.com/) reports provide standard ranges below which are deemed low and above which are deemed high values. Comparing with analyses for the 2011 and 2012 NWFP silages, the digestibility and metabolizable energy were either at the top of or exceeded the standard range. Those aspects which desirably are low (ammonia $\mathrm{N}$, acetic and butyric acid) were below the standard range-apart from ammonia $\mathrm{N}$ in August 2012. The ability to finish animals from forage to negate the use of human edible feed, fed as concentrates, will be driven on the quality of grazing and home-grown silage with DOMD > $700 \mathrm{~g}$ DOM/kg; ME > $11 \mathrm{MJ} / \mathrm{kg}$ and crude protein between 120 and $160 \mathrm{~g} / \mathrm{kg}$ [29].

\subsection{Cattle Performance}

In both years in the first winter after weaning the calves were supplemented on average with $0.27 \mathrm{~kg}$ concentrates/day (when expressed over the whole housed period) and they grew at $0.50 \mathrm{~kg} /$ day. Wright et al. [30] fed weaned suckled calves with silage supplemented with 1.2, 2.1 or $2.9 \mathrm{~kg}$ barley/head/day. Daily liveweight gains were $0.31,0.58$ and $0.79 \mathrm{~kg} / \mathrm{day}$. Furthermore, McGee et al. [31] reported a growth rate of $0.57 \mathrm{~kg} / \mathrm{d}$ for spring-born weaned beef calves during first 
winter housing and supplemented with $0.50 \mathrm{~kg}$ of concentrate. From this data, it is suggested that a benchmark target growth rate for the weaned calves in subsequent years on the NWFP should be around $0.5 \mathrm{~kg} /$ day with an aim to achieve $0.6-0.7 \mathrm{~kg} /$ day with improved forage characteristics (digestibility and crude protein) with strategic supplementation applied if targets are not met (i.e., poor silage nutritional value).

No additional concentrate supplementation was fed to the yearling cattle after they were turned out to graze in mid-April each year. Tyson et al. [32] reported growth rates for yearling beef cattle grazing at the North Wyke site between 1983 and 1987 which averaged $0.8 \mathrm{~kg} /$ day. In subsequent grazing seasons, rotationally stocked yearling dairy heifers grew at $0.84 \mathrm{~kg} /$ day [33]; whereas, yearling beef $x$ dairy heifers grew at $1.0 \mathrm{~kg} /$ day [34]. Also, Boland et al. [35] found that Limousine heifers (12-18 mo) grazing a permanent pasture in Ireland grew at a rate of $0.73-0.88 \mathrm{~kg} / \mathrm{d}$ depending on herbage allowance, whilst Black et al. [36] reported $0.99 \mathrm{~kg} / \mathrm{d}$ from steers grazing on grass pasture. Similar results were reported by Regan et al. [37] who observed liveweight gains between 0.80 and 0.87 for late and early maturing bulls, respectively, grazing pastures dominated by L. perenne and by McGee at al. [31] who reported a growth rate of $0.90 \mathrm{~kg} / \mathrm{d}$ for spring-born weaned beef calves since turnout to slaughter in Ireland. Therefore, it is suggested that a target benchmark growth rate for summer grazing should be $0.9 \mathrm{~kg} /$ day and this was slightly exceeded in this study (mean $0.96 \mathrm{~kg} /$ day). Future targets based on improved pasture must look to achieve 1.0-1.2 kg/day [3].

In 2011 and 2012, respectively, 40\% and 74\% of the spring-born cattle were housed for a second winter. The higher \% in 2012 was due in part to the cattle requiring to be housed in late September/early October as opposed to early November in 2011. In a previous beef demonstration system based on beef $x$ dairy heifers run at North Wyke [38], the target growth rate in the second winter finishing period based on silage and low levels of supplementation was $0.8 \mathrm{~kg} /$ day and this value is suggested for the experiments reported here. This target was achieved in $2011(0.81 \mathrm{~kg} /$ day $)$ and exceeded in 2012 $(1.04 \mathrm{~kg} /$ day $)$, similar to the values reported by Regan et al. [37] who recorded growth rates between 1.08 and $1.13 \mathrm{~kg} / \mathrm{d}$ for late and early maturing bulls, respectively, supplemented fed with silage and supplemented with $3.5 \mathrm{~kg}$ of concentrate. The greater growth rate achieved in the second winter 2012 could have been due to a degree of compensatory growth since the groups of animals that had the lowest growth rates in the first winter $(0.39$ and $0.46 \mathrm{~kg} /$ day, farmlets B and C, respectively) grew the greatest in their second winter (1.12 and $1.06 \mathrm{~kg} /$ day). As indicated previously, only in 2011 was some additional rolled barley fed to the remaining housed finishing cattle and when expressed per 25 cattle on each farmlet this amounted to $59.4 \mathrm{~kg} / \mathrm{head}$ in total in this second winter. This indicates that we can benchmark performance levels in a second housing period of $0.8-1.0 \mathrm{~kg} / \mathrm{d}$. However, the aim should always be to finish animals at pasture to avoid a second winter housing, highlighting the importance of targeting the growth rates at pasture towards $1.0-1.2 \mathrm{~kg} / \mathrm{d}$, which will be a major focus in the coming years on the NWFP when assessing the new pasture treatments [3].

\subsection{Sheep Performance}

The poor weather (high rainfall and low levels of sunshine) in 2012 compared with 2011 had a much greater impact on the sheep performance than was seen for the cattle. It affected mainly the pre-weaning daily liveweight gain (DLWG) since the weaning LW were 16\% lower in 2011 compared with 2012. This might be explained by the markedly lower solar radiation in April and June 2012 which is expected to have decreased pasture growth and energy content at early lactation and at the last month before weaning, with energy intake being the main nutritional factor determining milk yield of the ewe [39]. Particularly in April, the typical early-spring imbalance between crude protein and water-soluble carbohydrates, that is, readily-available energy in the rumen [40], might have been augmented given the low levels of radiation (lower production of water-soluble carbohydrates).

Overall, the weaning weights at a similar age in 2012 were proportionately 0.84 of those in 2011. Assuming an average birth weight of $4.9 \mathrm{~kg}$, this would imply an average daily liveweight gain of $306 \pm 56.5$ and $258 \pm 60.3 \mathrm{~g} /$ day from birth to weaning for 2011 and 2012, respectively. Those growth 
rates are similar to those obtained for grass-based sheep systems in Ireland. Keady et al. [41] reported growth rates from birth to weaning of $297 \mathrm{~g} /$ day for lambs born from ewes grazing until mid-gestation and then housed until lambing. Keady et al. [42] reported a growth rate of $267 \mathrm{~g} /$ day for lambs from ewes with an extended grazing period during winter. Slightly lower values were reported by Treacher et al. [43], who recorded a growth rate between 237 and $252 \mathrm{~g} / \mathrm{d}$ for twin and single lambs and Fraser at al. [44] who observed a growth rate from birth to weaning of $241 \mathrm{~g} / \mathrm{d}$. A benchmark target for lamb growth weights therefore would be around 250-300 g/d for future interventions on the NWFP. The poor lamb performance in 2012 was probably the result of a particularly extreme year and the better weather conditions in 2011 resulted in a level of performance which might more reasonably be expected for permanent pastures as a benchmark.

\subsection{Implications}

We ran cattle and sheep production systems based on permanent pastures on the NWFP. The livestock were reared and finished using minimal inputs of supplementary concentrates to establish realistic target growth rates on forage-based systems. Setting such targets is vital to redefine the potential of ruminants to produce high quality food without competing with human-edible feed. It is suggested that target liveweight gains should be $0.5 \mathrm{~kg} /$ day in the first winter; $0.9 \mathrm{~kg} / \mathrm{day}$ for summer grazing and $0.8 \mathrm{~kg} /$ day for cattle housed and finished on silage in a second winter. Lambs growth rates of $250-300 \mathrm{~g} / \mathrm{d}$ from birth to weaning and of 150-200 g/d from weaning to finishing could be set as a benchmark.

Even though finishing lambs at pasture is the conventional production system for lowland grasslands, some alternative feeding options may be included to finish lambs indoor or for specialist early lambing flocks which aim to market lambs in spring when prices are traditionally high, for example silage, concentrate, total mixed rations or by products [45], reaching growth rates above $300 \mathrm{~g} / \mathrm{d}[46,47]$. However, whether this alternative is economically convenient will depend upon the feed conversion efficiency and the prices of feed and meat. Although this strategy may have a positive impact on farm profit, it will be considered less 'natural' by the consumer and will reduce the animal's ability to express natural behaviour, which is deemed a positive metric of animal welfare [48]. It is also counter to the beneficial role of ruminants in countering the food versus feed debate, where ruminant livestock should not compete with human edible food [3]. Furthermore, meat from forage-fed lambs has high concentrations of n-3 polyunsaturated fatty acids (PUFA) including 18:3 (a-linolenic acid) and 20:5 (eicosapentaenoic acid) and higher flavour scores compared with concentrate-fed lambs [49]. Subsequently, other variables than animal performance should be considered when selecting the finishing strategy for lambs.

In many countries grain-feeding is necessary because of climatic limitations on the quality and quantity of pasture available [50]. Finishing cattle on concentrate-based diets may have a relevant impact on growth rate, increasing the DLWG between $18-60 \%$ on average compared with forage base diets which means that cattle can reach greater carcass weights and level of fat cover at a younger age [50]. Increasing animal performance can have a positive effect on environmental impact by reducing emissions intensity, that is, $\mathrm{kg} \mathrm{CO}_{2} \mathrm{e} / \mathrm{kg}$ beef carcass. However, findings are not consistent in this effect which would depend on different factors, for example, region, breed type, feeding strategy, level of management and technical efficiency [51].

Despite the suckler beef herd providing the main supply of prime beef in the UK, slightly more total beef comes from the dairy herd [52]. This has clear implications on the environmental impact of beef supply since dairy-based beef production showed largest potential to mitigate environmental impacts of beef, as emissions can be offset via milk production [53]. On the other hand, the proportion of potentially human-edible feed in the total feed input and the ratio of animal protein output to human-edible protein input is slightly lower in lowland suckler beef compared with dairy beef systems, although the land required per tonne of animal protein output has the opposite trend [3]. Moreover, there are also differences in meat quality when comparing a standard concentrate diet or a forage-base 
diet for either dairy or beef breeds; the grass silage diet produces higher plasma and muscle levels of vitamin E, lower lipid oxidation in loin steaks measured and better colour stability (saturation) [54].

\section{Conclusions}

It is concluded that good levels of livestock production are possible on permanent pastures with continuously stocked yearling beef cattle and ewes and their twin lambs on forage-based systems using little or no additional supplementary concentrate feeds. However, the variation in weather conditions across years can play a significant effect on grazing system performance. The NWFP will further investigate alternatives to permanent pasture to optimise production of forage-based ruminant production systems at the same time as assessing sustainability associated with environmental, economic and social need [55].

Author Contributions: Conceptualization, R.J.O.; methodology, R.J.O. and B.A.G. data curation, R.J.O. and B.A.G.; formal analysis, R.J.O. and M.J.R.; writing—original draft preparation, R.J.O.; writing—review and editing M.J.R. and M.R.F.L.; supervision, M.R.F.L.; project administration, R.J.O.

Funding: The North Wyke Farm Platform is a UK National Capability supported by the Biotechnology and Biological Sciences Research Council (BBSRC BB/J004308/1). Support in writing up the work was greatly received by the Biotechnology and Biological Sciences Research Council (BBSRC) through the strategic programmes Soil to Nutrition (S2N; BBS/E/C/000I0320) and Achieving Sustainable Agricultural Systems (ASSIST; BBS/E/C/000I0130) at Rothamsted Research.

Acknowledgments: This paper is dedicated to the remarkable contribution Robert Orr made to grazing livestock systems in a career that spanned more than 40 years, who was instrumental in the development and implementation of the North Wyke Farm Platform. Sadly, Robert passed away during the development of this paper and will be greatly missed by all who had the pleasure of meeting and working with him. This work was carried out in accordance with the welfare standards approved by Rothamsted Research, North Wyke's Animal Welfare Ethical Review Board. We would also like to acknowledge and thank Hannah Fleming and Simon White for the care of the animals and collection of the data; Katherine Tozer, Deborah Beaumont and Anita Shepherd who performed the botanical composition analysis.

Conflicts of Interest: The authors declare no conflict of interest. The funders had no role in the design of the study; in the collection, analyses or interpretation of data; in the writing of the manuscript or in the decision to publish the results.

\section{References}

1. Llonch, P.; Haskell, M.J.; Dewhurst, R.J.; Turner, S.P. Current available strategies to mitigate greenhouse gas emissions in livestock systems: An animal welfare perspective. Animal 2017, 11, 274-284. [CrossRef]

2. Mellor, D.J. Positive animal welfare states and reference standards for welfare assessment. N. Z. Vet. J. 2015, 63, 17-23. [CrossRef] [PubMed]

3. Wilkinson, J.M.; Lee, M.R.F. Use of human-edible animal feeds by ruminant livestock. Animal 2017, 12, 1735-1743. [CrossRef]

4. Smil, V. Eating meat: Constants and changes. Glob. Food Sec. 2014, 3, 67-71. [CrossRef]

5. Agriculture and Horticulture Development Board. AHDB Beef and Lamb, Stocktake Report 2016; AHDB Beef \& Lamb: Kenilworth, UK, 2016. Available online: http://beefandlamb.ahdb.org.uk/wp-content/uploads/2016/ 11/Beef-Lamb-Stocktake-Report-2016-281116.pdf (accessed on 2 June 2017).

6. $\quad$ Eisler, M.C.; Lee, M.R.F.; Tarlton, J.F.; Martin, G.B.; Beddington, J.; Dungait, J.A.J.; Greathead, H.; Liu, J.; Mathew, S.; Miller, H.; et al. Steps to sustainable livestock. Nature 2014, 507, 32-34. [CrossRef] [PubMed]

7. Röös, E.; Patel, M.; Spangberg, J.; Carlsson, G.; Rydhmer, L. limiting livestock production to pasture and by-products in a search for sustainable diets. Food Policy 2016, 58, 1-13. [CrossRef]

8. Orr, R.J.; Murray, P.J.; Eyles, C.J.; Blackwell, M.S.A.; Cardenas, L.M.; Collins, A.L.; Dungait, J.A.J.; Goulding, K.W.T.; Griffith, B.A.; Gurr, S.J.; et al. The North Wyke Farm Platform: Effect of temperate grassland farming systems on soil moisture contents, runoff and associated water quality dynamics. Eur. J. Soil Sci. 2016, 67, 374-385. [CrossRef] [PubMed] 
9. Neely, C.; Fynn, A. Critical Choices for Crop and Livestock Production Systems that Enhance Productivity and Build Ecosystem Resilience; SOLAW Background Thematic Report-TR11; FAO: Rome, Italy, 2012; p. 38. Available online: http://www.fao.org/fileadmin/templates/solaw/files/thematic_reports/TR_11_web.pdf (accessed on 26 January 2019).

10. Oliveros, M.C.R.; Park, K.M.; Kwon, E.G.; Choi, N.J.; Chang, J.S.; Hwang, I.H. Carcass traits and the quality of meat from cattle finished on diets containing barley. Asian Australas J. Anim. Sci. 2009, 22, 1594-1608. [CrossRef]

11. English Beef and Lamb Executive. Marketing Prime Lamb for Better Returns, EBLEX Sheep Manual 1; AHDB Beef \& Lamb: Stoneleigh Park, UK, 2012. Available online: http://beefandlamb.ahdb.org.uk/wp/wp-content/ uploads/2016/01/BRP-Marketing-prime-lamb-manual-1-180116.pdf (accessed on 20 April 2017).

12. English Beef and Lamb Executive. Marketing Prime Beef Cattle for Better Returns, EBLEX Beef Manual 2; AHDB Beef \& Lamb: Stoneleigh Park, UK, 2012. Available online: http://beefandlamb.ahdb.org.uk/wp-content/ uploads/2018/05/Marketing-prime-lamb-for-better-returns-300418.pdf (accessed on 20 April 2017).

13. Rodwell, J.S. Volume 3: Grasslands and Montane Communities. In British Plant Communities; Cambridge University Press: Cambridge, UK, 1992; p. 550.

14. Newton, J.E.; Betts, J.E.; Orr, R.J.; Wilde, R.M.; Dhanoa, M.S. The Effect of Time of Lambing on Sheep Production; GRI Technical Report No. 30; The Grassland Research Institute: Hurley, UK, 1982.

15. Orr, R.J.; Parsons, A.J.; Penning, P.D.; Treacher, T.T. Sward composition, animal performance and the potential production of grass/white clover swards continuously stocked with sheep. Grass Forage Sci. 1990, 45, 325-336. [CrossRef]

16. Parsons, A.J.; Orr, R.J.; Penning, P.D.; Lockyer, D.R. Uptake, cycling and fate of nitrogen in grass-clover swards continuously grazed by sheep. J. Agric. Sci. 1991, 116, 47-61. [CrossRef]

17. Penning, P.D.; Gibb, M.J. The effect of milk intake on the intake of cut and grazed herbage by lambs. Anim. Prod. 1979, 29, 53-67. [CrossRef]

18. Allen, V.G.L.; Batello, C.L.; Berretta, E.J.L.; Hodgson, J.L.; Kothmann, M.; Li, X.; McIvor, J.; Milne, J.; Morris, C.; Peeters, A.; et al. An international terminology for grazing lands and grazing animals. Grass Forage Sci. 2011, 66, 2-28. [CrossRef]

19. Agriculture and Horticulture Development Board. Nutrient Management Guide (RB209). 2017. Available online: http://www.ahdb.org.uk/projects/RB209.aspx (accessed on 22 January 2019).

20. Salehi, A.; Fallah, S.; Sourki, A. Organic and inorganic fertilizer effect on soil CO2 flux, microbial biomass and growth of Nigella sativa L. Int. Agrophys. 2017, 31, 103-116. [CrossRef]

21. Davies, W. The Grassland Map of England and Wales: Explanatory Notes. Agriculture 1941, 48, $112-121$.

22. Rutter, S.M.; Orr, R.J.; Penning, P.D.; Yarrow, N.H.; Champion, R.A. Ingestive behaviour of heifers grazing monocultures of ryegrass or white clover. Appl. Anim. Behav. Sci. 2002, 76, 1-9. [CrossRef]

23. Agricultural Research Council. Chapter 2-Feed intake. In The Nutrient Requirements of Ruminant Livestock; Blaxter, K., Ed.; Commonwealth Agricultural Bureaux: Farnham Royal, UK, 1980; pp. 59-72.

24. Orr, R.J.; Martyn, T.M.; Clements, R.O. Evaluation of perennial ryegrass varieties under frequent cutting or continuous stocking with sheep. Plant Var. Seeds 2001, 14, 181-199.

25. Orr, R.J.; Treacher, T.T. Intakes of silages, hays and straws by ewes in mid pregnancy. Anim. Prod. 1990, 51, 301-310. [CrossRef]

26. Orr, R.J.; Treacher, T.T. The effect of concentrate level on the intake of grass silages by ewes in late pregnancy. Anim. Prod. 1989, 48, 109-120. [CrossRef]

27. Orr, R.J.; Treacher, T.T. Erratum. Anim. Prod. 1992, 55, 299. [CrossRef]

28. Orr, R.J.; Treacher, T.T. The effect of concentrate level on the intakes of silages or hays by ewes in the 1st month of lactation. Anim. Prod. 1994, 58, 109-116. [CrossRef]

29. English Beef and Lamb Executive. Making Grass Silage for Better Returns, EBLEX Beef and Sheep BR Manual 5; AHDB: Ambury Road South, UK, 2011. Available online: http://beefandlamb.ahdb.org.uk/wp-content/ uploads/2013/06/Manual-5-makinggrasssilageforbetterreturns070211.pdf (accessed on 20 April 2017).

30. Wright, I.A.; Russel, A.J.F.; Hunter, E.A. Nutrition and performance of weaned suckled calves. In Hill Farming Research Organisation Biennial Report 1982-83; Hill Farming Research Organisation: Penicuick, UK, 1983; pp. 153-158. 
31. McGee, M.; Drennan, M.; Crosson, P. Effect of concentrate feeding level in winter and turnout date to pasture in spring on biological and economical performance of weanling cattle in suckler beef production systems. Ir. J. Agric. Food Res. 2014, 53, 1-19.

32. Tyson, K.C.; Garwood, E.A.; Armstrong, A.C.; Scholefield, D. Effects of field drainage on the growth of herbage and the liveweight gain of grazing beef cattle. Grass Forage Sci. 1992, 47, 290-301. [CrossRef]

33. Orr, R.J.; Rutter, S.M.; Yarrow, N.H.; Champion, R.A.; Rook, A.J. Changes in ingestive behaviour of yearling dairy heifers due to changes in sward state during grazing down of rotationally stocked ryegrass or white clover pastures. Appl. Anim. Behav. Sci. 2004, 87, 205-222. [CrossRef]

34. Orr, R.J.; Cook, J.E.; Young, K.L.; Champion, R.A.; Rutter, S.M. Intake characteristics of perennial ryegrass varieties when grazed by yearling beef cattle under rotational grazing management. Grass Forage Sci. 2005, 60, 157-167. [CrossRef]

35. Boland, T.M.; Quinlan, C.; Pierce, K.M.; Lynch, M.B.; Kelly, A.K.; Purcell, P.J. The effect of pasture pre-grazing herbage mass on methane emissions, ruminal fermentation and average daily gain of grazing beef heifers. J. Anim. Sci. 2013, 91, 3867-3874. [CrossRef]

36. Black, A.D.; O'Kiely, P.; Moloney, A.P. Liveweight gains were similar in steers grazing perennial ryegrass cultivars bred for elevated or normal concentrations of water-soluble carbohydrates. In Proceedings of the 14th Symposium of the European Grassland Federation, Ghent, Belgium, 3-5 September 2007.

37. Regan, M.; McGee, M.; Moloney, A.P.; Kelly, A.K.; O’Riordan, E.G. Grass-based suckler steer weanling-to-beef production systems: Effect of breed and slaughter age. In Proceedings of the 27th General Meeting of the European Grassland Federation, Cork, Ireland, 17-21 June 2018.

38. Yarrow, N.H.; Orr, R.J.; Shields, R.W. Practice into profit: Low-input heifer beef production. In Beef from Grass and Forage, Proceedings of the British Grassland Society Conference, Tillington Hall, UK, 20-21 November 2000; Pullar, D., Ed.; British Grassland Society: Stafford, UK, 2000; pp. 173-174.

39. Pulina, G.; Macciotta, N.; Nudda, A. Milk composition and feeding in the Italian dairy sheep. Ital. J. Anim. Sci. 2005, 4, 5-14. [CrossRef]

40. Roche, J.R.; Turner, L.R.; Lee, J.M.; Edmeades, D.C.; Donaghy, D.J.; Macdonald, K.A.; Penno, J.W.; Berry, D.P. Weather, herbage quality and milk production in pastoral systems. 2. Temporal patterns and intra-relationships in herbage quality and mineral concentration parameters. Anim. Prod. Sci. 2009, 49, 192-199. [CrossRef]

41. Keady, T.; Hanrahan, J.; Flanagan, S. Effects of extended grazing during mid, late or throughout pregnancy and winter shearing of housed ewes, on ewe and lamb performance. Ir. J. Agric. Food Res. 2007, 46, 169-180.

42. Keady, T.; Hanrahan, J.; Flanagan, S. An evaluation of two grassland-based systems of mid-season prime lamb production using prolific ewes of two genotypes. Ir. J. Agric. Food Res. 2009, 48, 87-101.

43. Treacher, T.T. The possibilities for improving the performance of ewes suckling three or more lambs in grazing systems. In Genetics of Reproduction in Sheep; Land, R.B., Robinson, D.W., Eds.; Butterworths: London, UK, 1985.

44. Fraser, M.D.; Valea, J.E.; Dhanoa, M.S. Alternative upland grazing systems: Impacts on livestock performance and sward characteristics. Agric. Ecosyst. Environ. 2013, 175, 8-20. [CrossRef]

45. English Beef and Lamb Executive. Growing and Finishing Lambs for Better Returns, EBLEX Beef Manual 5; AHDB: Stoneleigh Park, UK, 2015. Available online: http://beefandlamb.ahdb.org.uk/wp-content/uploads/ 2014/07/brp-manual-5-Growing-and-finishing-lambs290714.pdf (accessed on 20 April 2017).

46. Brito, G.F.; Ponnampalam, E.N.; Hopkins, D.L. The effect of extensive feeding systems on growth rate, carcass traits and meat quality of finishing lambs. Compr. Rev. Food Sci. Food Saf. 2017, 16, 23-38. [CrossRef]

47. Jacques, J.; Berthiaume, R.; Cinq-Mars, D. Growth performance and carcass characteristics of Dorset lambs fed different concentrates: Forage ratios or fresh grass. Small Rumin. Res. 2011, 95, 113-119. [CrossRef]

48. Goddard, P.; Waterhouse, T.; Dwyer, C.; Stott, A. The perception of the welfare of sheep in extensive systems. Small Rumin. Res. 2006, 62, 215-225. [CrossRef]

49. Fisher, A.V.; Enser, M.; Richardson, R.I.; Wood, J.D.; Nute, G.R.; Kurt, E.; Sinclair, L.A.; Wilkinson, R.G. Fatty acid composition and eating quality of lamb types derived from four diverse breed $\times$ production systems. Meat Sci. 2000, 55, 141-147. [CrossRef]

50. Muir, P.D.; Deaker, J.M.; Bown, M.D. Effects of forage- and grain-based feeding systems on beef quality: A review. N. Z. J. Agric. Res. 1998, 41, 623-635. [CrossRef] 
51. Crosson, P.; Shalloo, L.; O’Brien, D.; Lanigan, G.J.; Foley, P.A.; Boland, T.M.; Kenny, D.A. A review of whole farm systems models of greenhouse gas emissions from beef and dairy cattle production systems. Anim. Feed Sci. Technol. 2011, 166-167, 29-45. [CrossRef]

52. AHDB Beef \& Lamb. Available online: http://beefandlamb.ahdb.org.uk/market-intelligence-news/thesource-of-beef-production/ (accessed on 15 February 2019).

53. De Vries, M.; van Middelaar, C.E.; de Boer, I.J.M. Comparing environmental impacts of beef production systems: A review of life cycle assessments. Livest. Sci. 2015, 178, 279-288. [CrossRef]

54. Warren, H.E.; Scollan, N.D.; Nute, G.R.; Hughes, S.I.; Wood, J.D.; Richardson, R.I. Effects of breed and a concentrate or grass silage diet on beef quality in cattle of 3 ages. II: Meat stability and flavour. Meat Sci. 2008, 78, 270-278. [CrossRef] [PubMed]

55. Takahashi, T.; Harris, P.; Blackwell, M.S.A.; Cardenas, L.M.; Collins, A.L.; Dungait, J.A.J.; Hawkins, J.M.B.; Misselbrook, T.H.; McAuliffe, G.A.; McFadzean, J.N.; et al. Roles of instrumented farm-scale trials in trade-off assessments of pasture-based ruminant production systems. Animal 2018, 12, 1766-1776. [CrossRef] [PubMed]

(C) 2019 by the authors. Licensee MDPI, Basel, Switzerland. This article is an open access article distributed under the terms and conditions of the Creative Commons Attribution (CC BY) license (http://creativecommons.org/licenses/by/4.0/). 